\title{
The Immanent Subject of Music
}

\author{
Medushevsky Vyacheslav \\ Moscow P.I. Tchaikovsky Conservatory. \\ Moscow, Russia \\ e-mail: vmedu@mail.ru
}

\begin{abstract}
The article analyzes the notion of music's immanent subject, which lives in sounds, like the soul in the body, which is represented in Spiritual, Medieval and New European music. It is noble in high music, moves towards the sky and brings inspiration. This synergy vertical defines the slightest details of music hypertext of culture \& literature: music language, the system of styles and genres, music in all varieties of masterpieces.
\end{abstract}

Keywords—music; beauty; music culture; music performing; Orthodoxy

\section{INTRODUCTION}

The immanent subject of music is captured in the sounds, revealed in them like the soul in the body.

What is this concept for? It is there because it is impossible to communicate with the object content. How to communicate with sticks, logs and clubs? They exist but don't live. Music is alive and gives life. Hence, it is the subject and not the object. A look at music from this side will open a lot that is imperceptible by an objectivist approach.

What is it, the immanent subject of music, in masterpieces?

It may seem that in its analysis it is necessary have a look at what the bible has to say.

It should be started not from the present but from the eternity, not from the swamp but from the tops. The bottom does not communicate with the top. Common anthropology can't embrace spirituality. In the words of the Apostle: «The person without the Spirit does not accept the things that come from the Spirit of God...The person with the Spirit makes judgments about all things, but such a person is not subject to merely human judgments, for, who has known the mind of the Lord so as to instruct him? But we have the mind of Christ» (1 Corinthians, 2-14).Cartesian sham matter and supposedly thinking subject will always be an implacable enemy of the spiritual man craving to live in truth and beauty. The singing of sham matters will not endure to the chanting. The feat of beauty cognition is alien to their notes playing. The reduction of anthropological concepts is the fruit of reverse evolution (i.e. of the revolution which is a rollback, slide into the abyss). Christ compared this history line with the aging of tares on a wheat field. Saint Augustine continued the revelation of Christ on the fundamental heterogeneity of history in the doctrine of the two cities invisible coexisting in human society.

The city of God based on love to God resists the city of earth based on self-love in contempt for God. Swamp is excited to announce itself modern (but it doesn't know the true meaning of modernity), in order to tighten into a quagmire as many people as possible. But freedom is irrevocable: swampers have the opportunity to repent by making life-saving choices.

\section{DEVELOPMENT OF THE IMMANENT SUBJECT}

God created man in His own image and likeness breathed into his nostrils the breath of life: that's the foundation of anthropology. Is it bad to be the image and breath of God and to wish for living in God?

In this case, the music comes down from above, begins to serve the divine-human communication. Under the sound of the dulcimer the Spirit of God was coming down on the prophet Elisha and other prophets and they prophesied. Three young men with the angel sang $t$ glory to God in the incandescent furnace and thanks to such miracles the king Nebuchadnezzar repented.

Synodic unity in God is embodied in the music of the Church. The basis of its beauty was unprecedented anthropology of the Christian faith. People are commanded to dwell in the depths of the Trinitarian love of God, so that God shall live in them (John. 15:4)! It is the Kingdom of God which's entrance to humanity was opened by Christ. «The Kingdom of God is in your midst.» (Luke, 17:21) this is not psychology but ontology: the true exisitng of mankind in God, distinctive from the husk of pseudoexistence. The amazing formula of a renewed man: he himself is God's temple and God's Spirit dwelling in his midst! (1 Corinthians 3:16).

God's Spirit also created another unheard sound - the sound of the coming of Christian civilization, which's beauty must be submitted to by the entire world. The sound, free of selfish-sinful clamps is apparently unearthly in its purity, not abstract-cold but warmed with tenderness, filled with heavenly love, glowing hope of bliss, is full of humility and encloses all the Christian virtues. Together with this sound Christian intonation and syntax evolved, modal form selected. Holy music theory overheard angel tone revelation of heavenly music helped to all this. Later revelations of polyphony, harmonic organization and more complicated forms were received. 
Millennial development of church music laid the foundation for secular music. Saturated with Christian ontology, secular music continued the miraculous act of culture creating in a new direction - the spiritualization outside of temples. The temple is not enough for salvation. More space to be patient in times of sorrows and temptations, in keeping the commandments in all the diverse circumstances proposed by God is needed. Like the Fathers say, no one would have been saved. Music began to absorb all circumstances of life, including temptation, passion and dramatic collisions. But why? The highest goal of secular music is to pull us out of the swamp of criminal coldness to Heaven, thanks to the calling grace of God which offers a very different life full of inspiration and meaning. One example is when the Baroque era started, the most important era of pathetic music, which's essence has been seen in the greatness of the soul to the measure its sacrifice. "Passion" of the Lord became very important and the plot of the operaseria and the abundance of instrumental compositions camped around. For example, it is impossible to imagine Bach without pathos. Music such as intonation gospel began to teach the people to repent with crys of love, courage of spiritual sacrifice, hope, jubilation of the glory of God and gentle conversations like in paradise...

Who is the author of musical hypertexts of culture and history, the musical language of all styles and genres, music throughout the variety of its masterpieces filled with faith, hope, love and grace?

It is not human notion to build a temple of internal Christianity in the culture and music of our civilization! Myriad subtleties of musical language, which are now used by the whole world, the wealth of polyphonic techniques, and the revelation of harmony, texture and musical form they all are created by God. The Holy Spirit was creating beauty and musicians were making sense of life and inspiration by assisting divine beauty.

The hypertext author of the beautiful music of humanity, therefore, is its immanent subject - God dwelling in the living temple of the soul of humanity. God is not envious, not irritable and not boastful. He has given His excellence in the commandments to people - so they tried to imitate Him for life with Him and in Him. «Be holy, because I am holy» (Leviticus, 11:45; 1 Peter, 1:16). «Be perfect, therefore, as your heavenly Father is perfect. (Matthew, 5:48). «God is love» (1 John, 4:8,16). From the Love hymn by Apostle Paul: «Love is patient, love is kind. It does not envy, it does not boast, it is not proud. It does not dishonor others, it is not self-seeking, it is not easily angered, it keeps no record of wrongs. Love does not delight in evil but rejoices with the truth. It always protects, always trusts, always hopes, always perseveres. Love never fails ...» (1 Corinthians, $13: 4-8)$.

The whole structure of the properties of God came into music and is reflected in all of it, even in the smallest properties and qualities, that every man has it easier to live with the holiness of God. Here an inexhaustible spring of the transforming power of music becomes clear, as well as the source of its historical development.

\section{DIFFERENTIATING AND ANALYZING MUSIC}

«Music is literally the memory of our body about the history of creation, ") says Maximilian Voloshin. Perhaps it is. But the memory of a providential sense of history and the future is even clearer, as musical development has always had a goal and strict movement to it.

Only music's immanent character and those real musicians who come with him in conciliar fellowship before God can perceive the most hidden meaning of music. The first sign of such a contact is God's responsible management of music continuity.

Attacks on noble, always aspiring to Heaven soul of the immanent subject of high music, come from two sides.

By highbrow theory secular music indiscriminately and without evidence allegedly made itself throng of passions (Vl. Martynov, arch. Rafail Karelin). Passion in asceticism is a sinful distortion of God-created human forces. In passion man is passive; he turns from the subject of life into the object, into the playground of demonic forces. If it was so, serious music would be no different from aggressive rock or pop music. It is not taken into account here that the spiritual will of the subject of music that reflects the higher meaning of music always dominates all the ups and downs of internal music scene, sometimes affecting moments of temptations. Are, for example, intimidation and some oppression of the soul by fear of death in the introduction of Tchaikovsky's Fifth Symphony not the norm of human existence? But the immanent subject passes its way, trying to dislodge the memory of death, which is impossible, but at the end of the symphony he finds the right way out in joyous praise of Christ's eternal victory, to its joy, to the eternal kingdom of love and light all people are called to.

Through vulgarly performing, aggression against the height of music is to replace the subject of music based on the vulgar theory of derelict emotions and unmanned life circumstances. If there is no immanent subject of music, it is easy to replace it by me, music yoot. And if the emotions are mine I can play like I want. This lie is exposed by comparing brilliant and mediocre performances.

In both cases, a patient analysis of music is required, they reveals the beauty of the immanent subject of music in the aspect of divine-human communication.

One of such an analysis will be given now. Chopin's first ballad will show us the importance of subject's feeling of high music for its proper understanding and fulfillment.

Music critics eagerly rush to the events and crises in the development of the inner music plot without thinking about the main thing - the heavenly nobility of the musical hero. This is wrong because it contradicts the logic of things. The living and life are correlative concepts (the "soul" is the subject of life, "life" is the journey of the soul), but the living appear to be the leader. It is so because people are the image of God. God is not the result of His being. On the contrary, with his absolute freedom $\mathrm{He}$ defines His existence as love, giving birth to the Son, and emitting the Spirit which represents the same. Accordingly, the created 
being of man is planned as the great miracle of communion with God.

Not taking into account the priority of the subjective side of existence, we fall into the trap of inadequacy. It is impossible to analyze internal content in any way. It should be in God. God sees not the actions themselves but what they are for the soul. In the words of St. John Chrysostom, "God kisses intentions."

Three crosses stood on Calvary: wicked robbers suffered hanging on hobnails but in the indomitable fury of passion blasphemed Christ and after death came to eternal torment. Catastrophe! A wise thief is first taken to heave. And how is taken! He is portrayed with a cross, i.e., as a martyr for Christ! Can ones tongue agree to talk about the catastrophe of life here? The third cross is entirely the cross of the Lord, in the words of Christ ( «I lay down my life - only to take it up again. No one takes it from me, but I lay it down of my own accord. I have authority to lay it down and authority to take it up again. This command I received from my Father» — John, 10:17).

The cross is the symbol of all the tests, the ills of life, sufferings and death, understandable in the providential sense for Christians - i.e., not as random, meaningless changes of destiny but received from the hands of God as some kind of job. «Dear friends, do not be surprised at the fiery ordeal that has come on you to test you, as though something strange were happening to you. But rejoice inasmuch as you participate in the sufferings of Christ, so that you may be overjoyed when his glory is revealed» (1 Peter, 4:12).

When a case is taken out of the hands of God it immediately turns into a bright sphere of divine-human communication. One should answer with the spirit strengthening, love to Him, inspired by faith, courageous determination and even enthusiasm for death for the sake of God's love.

This miracle of immense disclosure of the soul in life can be seen in tragic compositions.

How can it be lived through by those who are far from the immanent subject of high music, always noble and trusting to Heaven? With the gloom of their souls they replace the immanent subject of brilliant music and in this way humiliate all masterpieces. And destroy it, for the integrity and coherence of the reflected life in it is completely determined by the amount of celestial quality.

\section{Unhearing of miracle appears in verbal interpretations.}

Are they writing correctly about the crash at the end? This is slander. Are we facing the stinking death of evil robbers? Does is not the feat of the spirit, does it? It is unacceptable to talk about despair. Denial of aspirations is a mortal sin, blasphemy and lies are too.

Writing about the smashing and tearing is equivalent to the assertion of cowardice, deceit and treachery of the protagonist, who crossed out all the revelation of previous stages.
Chopin prescribes indication to perform con fuoco with fire. How it is possible to break with fire? Language does not allow such phrases because the courage fierce never gives the possibility to a cowardly-breaking soul.

The Christian soul of the immanent subject of ballads rushed to Heaven in its search, asking for love three times, and three times (in the conducting of the adverse party theme) obtained the desired according to the commandment promise: seek, and ye shall find. And when the time of death came the soul chickened out, broke, fell down, became a traitor of God's love like Judas, and croaked in shudder of fear?

All the causes of misunderstanding are reduced to a reluctance to see the most important feature of high music's soul - that it can't imagine its existence without Heaven and is committed to it till death.

With an adequate approach we hear the living soul of the immanent subject in the arms of divine love, in the greatness of the feat and the overthrow of death. Hence there is a victoriously-inspiring effect at the end.

«But take heart! I have overcome the world», - The Lord says (John, 16:33). The music of a ballad becomes an expression of the Gospel revelation: "God is love" - and there is nothing more precious and beautiful for a man.

The notion of the immanent subject of music, important for performance practice and analysis, makes it possible to solve problems in science which can't be solved with an objectivistic approach. For example, it helps to solve the riddle of composition existence in a variety of interpretations. After all, if the content is the thing, then the multiplicity of different performances leads to the inevitable abstractness of a masterpiece and its graying. A mix between black and white - it's not mediocrity, is it? In the addition of +1 with -1 - there is zero as a result, isn't it? The triangle in general is not isosceles, not equilateral, not versatile, not rectangular, not acute-angled, and not obtuseangled - isn't it an empty abstraction? In the world of the rational abstractions the philosophically abstracted god becomes such a single-order abstracted "geometrical point", "ideal gas", "absolutely blackbody". To such an abstract God there is an abstract way through transcendence which has nothing to do with the living communion with God.

\section{CONCLUSION}

If the music content is not a thing but a living subject in its lively living testimonies of God, then becoming ordinary and falling into tedious abstractness is excluded: the same revelation, which was given to Beethoven, Tchaikovsky or Rachmaninoff, gives life to brilliant performances. It's just the same but also takes into account the new historical circumstances, the sound of specific instruments, the acoustics of the hall, the audience characteristics and thousands of other details. It renews the masterpiece ascending to Heaven like an eternally reborn phoenix in brilliant performances.

The powers of communion with God are poured performers and listeners being renewed in spiritual joy. 
Objectivistic understanding of the content is formed by the structure, and a living "me" of the immanent subject of music does not form up. It lives: pervasive throughout the work space, it is presents itself from its first and to its last note.

If the ultimate depth of content is living and life-giving rather than a subjective thing then all categories of art come to life together with an eternally youthful masterpiece: the truth, the truth of life, time coupled with eternity, smart light, faith and freedom captured in the form of beauty become life-giving... And there is nothing more unalive, and everything goes collectively to the eternal source of life, beauty and love, declaring the last goal of being, which is love between the Creator and his rational creation. Great music sounds from the future, calling us into the unstoppable approaching Kingdom. 